\title{
Intermédialités
}

Histoire et théorie des arts, des lettres et des techniques

Intermediality

History and Theory of the Arts, Literature and Technologies

\section{“As Regarding Rhythm”: Rhythm in Modern Poetry and Cinema}

\section{Sarah Keller}

Numéro 16, automne 2010

rythmer

rhythmize

URI : https://id.erudit.org/iderudit/1001959ar

DOI : https://doi.org/10.7202/1001959ar

Aller au sommaire du numéro

Éditeur(s)

Revue intermédialités (Presses de l’Université de Montréal)

ISSN

1705-8546 (imprimé)

1920-3136 (numérique)

Découvrir la revue

Citer cet article

Keller, S. (2010). “As Regarding Rhythm”: Rhythm in Modern Poetry and

Cinema. Intermédialités / Intermediality, (16), 129-143.

https://doi.org/10.7202/1001959ar
Résumé de l'article

Cet essai s'intéresse à la relation qu'entretiennent la poésie moderne et le cinéma dans leur rapport privilégié au rythme. Notre étude établit que le rythme offre un mode alternatif de structuration des films non narratifs tout en fournissant une explication sur la conception des mécanismes du cinéma chez les réalisateurs des cercles modernistes. 


\title{
“As Regarding Rhythm”: Rhythm in Modern Poetry and Cinema
}

\author{
Sarah Keller
}

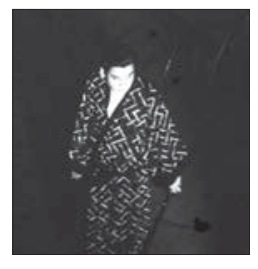

The "age demanded" chiefly a mould in plaster,

Made with no loss of time,

A prose kinema, not, not assuredly, alabaster

Or the "sculpture" of rhyme.

Ezra Pound, from "Hugh Selwyn Mauberley"

As regarding rhythm: to compose in the sequence of the musical phrase, not in sequence of a metronome.

Ezra Pound, one of three tenets of Imagism ${ }^{1}$

ne of the recurring ways in which the story of cinema's development as an art form has been told involves a series of lamentations; over lost possibilities, over wrong emphases on certain cinematic objectives, over technological changes that have rendered the old and better ways obsolete. Having fueled some of the enduring theories of the cinema, these lamentations appear to arise as highly productive moments of reflection on the purview of cinema. In this manner of thinking, specific movements or trends-Italian Neo-Realism, widescreen, deep staging, etc. - reflect a way of thinking about the cinema's proper means of expression. One particularly strong lament periodically arising in avant-garde

1. Ezra Pound, "Hugh Selwyn Mauberly," Selected Poems, New York, New Directions, 1957, p. 62, and Ezra Pound, "A Retrospect," in T.S. Eliot (ed.), Literary Essays of Ezra Pound, London, Faber and Faber, 1954, p. 3. The image is a still from Maya Deren's Season of Strangers (1959), also known as Haiku Film Project. 
circles grieves the emergence and eventual hegemony of narrative integration over a "pure cinema," or, less extreme, over the artistic and expressive capacities uniquely available to the medium that lie outside the zone of narrative concerns. ${ }^{2}$ Although it continues in noteworthy ways into the $21^{\text {st }}$ century, the historical center of this lament lies in the 1910s and 1920s, galvanizing several filmmakers' sense of purpose at a moment when art in its many forms sought redefinition in response to the exigencies of modern life.

Equally so, and arising at the same moment, a central aspect of modernist literature and of modernist art more generally is that it inspired, and was inspired by, reflection on the crisis in form and substance for those practising and theorizing art across a variety of media in the 1910s-1920s (and beyond). ${ }^{3}$ It is worth noting that those working on both poetry and cinema at this moment fixate on the question of rhythm as a means of explaining the effects of their medium. Possibly the focus on rhythm is something of a byproduct of so many artists interested in what can be accomplished outside the stranglehold of narrative and/or more traditional forms. Whatever the reason for the coincidence, the connection between poetry and cinema regarding rhythm deserves scrutiny for what it can provide by way of explanatory device for how the cinema was understood at this moment when everything seemed possible for its emergence as a genuine form of art.

Rhythm serves as a cornerstone for both cinema and poetry in the modern era. It achieves functions not available so readily to narrative, nor for that matter to analytical reasoning. It proffers access to ineffable qualities, emotional dictates, criticism against the slumber of critical faculties, and for some authors, even spiritual revelation. ${ }^{4}$ Furthermore, rhythm serves a definitive formal function

2. Theories of the cinema developing in France in the 1920s often hinged on debates surrounding pure cinema. For further discussion, see Richard Abel, French Film Theory and Criticism, vol. 1, Princeton, Princeton University Press, 1988.

3. For discussion on the formal crises associated with modernism in general, see Malcolm Bradbury and James McFarlane, "The Name and Nature of Modernism," in Malcolm Bradbury and James McFarlane (eds.), Modernism: A Guide to European Literature 1890-1930, New York, Penguin Books, 1991, p. 19-55.

4. Though they are central as well to modernism, these functions are of course not limited to the modern context. As one of Emily Dickinson's suggestive poems alerts the reader, confronting experience with rational, straightforward approach often doesn't work: "There's a certain slant of light" that guides us to "internal difference/Where the meanings are." Emily Dickinson, "There's a Certain Slant of Light," The Complete Poems of Emily Dickinson, ed. Thomas H. Johnson, Boston, Little Brown and Co., 1961, p. 118. 
for both arts. Léon Moussinac, one of several writers in France in the 1920s to seize upon the importance of rhythm in constructing cinematic art, notes that rhythm fulfils a fundamental role in filmmaking: "To edit a film is nothing more than to give it rhythm." ${ }^{5}$ Like others in his milieu, Moussinac connects cinema both to poetry and to other arts, most particularly music, in his consideration of its proper means of expression, linking the "symphonic poem" with the "cinegraphic poem." Modern poetry, keenly focused on the issue of rhythm, likewise summons musical analogies to its aid in describing the proper use of rhythm for poetic impact. The three cardinal tenets of Imagism as expounded by Ezra Pound, one of the most prolific proponents of rhythm as an aesthetic principle, conclude by highlighting the role of rhythm vis-à-vis music in the construction of modern verse: "As regarding rhythm: to compose in the sequence of the musical phrase, not in sequence of a metronome." Pound frequently returns to the idea of rhythm relative to music to argue for effective methods of poetic phrasing, as we shall see.

The charm of a poetic model for cinema is that it grants a point of access for thinking about some of the cinema's power that is not fully accounted for in other models. John Hollander (among many others) has noted that there is a strong relationship between poetry and music and other oral traditions, as well as between poetry and the ineffable or magical (its incantatory powers): "Poetic form as we know it is an abstraction from, or residue of, musical form, from which it came to be divorced when writing replaced memory as a way of preserving poetic utterance in narrative, prayer, spell, and the like." ${ }^{8}$ Other poets have noted the ability of verse to transfer feeling to the reader. Louis Zukofsky, for instance, argues that " $t]$ he music of verse carries an emotional quality; when the music slackens, emotion dissipates, and the poetry is poor." 9 T.S. Eliot provides an important note of caution for this view, assuring us that the musicality of poetry is not its only important quality: "I would remind you, first, that the music of poetry is not something which exists apart from the meaning." ${ }^{10}$ Poetry makes

5. Léon Moussinac, "On Cinegraphic Rhythm," in Abel, 1988, p. 281.

6. Ibid., p. 282.

7. Pound, 1954, P. 3 .

8. John Hollander, Rhyme's Reason: A Guide to English Verse, New Haven, Yale University Press, 2000, p. 5.

9. Louis Zukofsky, A Test of Poetry [1948], Hanover, University Press of New England, 2000 , p. 50.

10. T.S. Eliot, "The Music of Poetry," in Selected Prose of T.S. Eliot, ed. Frank Kermode, New York, Harvest, 1975, p. 110. 
careful structural use of the rhythm of words and silences to achieve effects of both sense and feeling.

Eliot's essay on "The Music of Poetry" is illustrative of the relativity of rhythm for poetry. He echoes Pound's "Hugh Selwyn Mauberley" in his assessment of gathering the proper materials for the construction of poetry and using the craft of poetry to shape those raw materials:

Of course, we do not want the poet merely to reproduce exactly the conversational idiom of $[\ldots]$ his particular district: but what he finds there is the material out of which he must make his poetry. He must, like the sculptor, be faithful to the material in which he works; it is out of sounds that he has heard that he must make his melody and harmony. ${ }^{11}$

In a general way, poems tend to engage several levels of meaning at once, which are more or less effected through rhythmic relations: first, there is the relative sense of the words in their apparent context (their denotative meanings) and the more far-ranging sense of the words as they exist in other contexts (connotative meanings, which either enhance or taint these denotative meanings). In addition to - and at least as important as - word choices, poems mobilize rhythm; they rhyme and line to generate meaning. The prosody of a line often contains dissonance as well as harmony: it is the relationship between them that counts. Moreover, relative stresses are apparent only based on context. As the poet Robert Pinsky describes it, rhythm emerges through engagement with "variations in degree of accent, variations in the difference between an unaccented syllable and an accented syllable, and a varying play between accent and duration." 12

Examining the intersection between cinema and poetry, especially in the modern era, offers several advantages, including that neither relies upon a strictly rational approach to defining their terms so that they illuminate each other. Taking this cue, Jean Epstein wrote approximately half of his first comprehensive theoretical statement on cinema in verse. ${ }^{13}$ Since then, several scholars have theorized the connection between poetry and cinema as well. ${ }^{14}$ Susan McCabe

11. Ibid., p. 112.

12. Robert Pinsky, The Sounds of Poetry: A Brief Guide, New York, Farrar, Straus and Giroux, 1998, p. 21.

13. Jean Epstein, Bonjour cinéma, Paris, Éditions Seghers, 1921.

14. P. Adams Sitney, Modernist Montage: The Obscurity of Vision in Cinema and Literature, New York, Columbia University Press, 1990, and Visionary Film: The American Avant-Garde 1943-2000, Oxford, Oxford University Press, 2003; and Susan McCabe, Cinematic Modernism, Cambridge, Cambridge University Press, 2005. See also Laura Marcus, The Tenth Muse: Writing About Cinema in the Modernist Period, Oxford, Oxford 
has most fully pursued the point of intersection between modern poetry and the cinema, however with very different results than those intended here. ${ }^{15}$ Whether a filmmaker, film theorist, or film scholar is concerned with forms that might more readily be comparable to poetic or musical structures, the theoretical implications of a model of cinema based on musical and poetic rhythm allow access to the region of meaning surpassing the bounds of causality, character motivation, or the various diegetic exigencies of a classical narrative cinema. It provides insight into the material means of cinema by focusing our attention on a level of meaning that transcends what Margaret Atwood has suggested is the purview of the typical plot: "a what and a what and a what," or even a "how and why." 16

The sheer number of filmmaker-theorists who have pursued the implications of poetry and cinema's connection indicates the attraction of this non-narrative direction for film art. Indeed, some of the most persistent theories of cinema have drawn upon models relative to poetry rather than narrative, despite narrative's hegemony across much of cinema's history. These theories-among them, formulations of the cinema by Jean Epstein, Germaine Dulac, René Clair, Sergei Eisenstein, Maya Deren, Hollis Frampton, Abigail Child, Ayman Mohktar and others-have emphasized cinema's alchemical, incantatory cadences and its likeness to music, dance, and the use of rhythm in poetry rather than to the prosaic concerns of narratives, where the plodding logic of causality enjoys a relatively uncontested reign.

University Press, 2008, and Daniel Kane's recent work on counterculture, poets, and cinema: Daniel Kane, “Not to Creation or Destruction but to Truth': Robert Duncan, Kenneth Anger, and the Conversation between Film and Poetry," Texas Studies in Literature and Language, vol. 8, ${ }^{\circ}$ 1, p. 34-57 and We Saw the Light, Iowa City, Iowa University Press, 2010.

15. However, McCabe and other scholars tend to focus on the work of modern poets whose work is inflected by the cinema rather than the other way around. Moreover, McCabe's interest lies in the fragmented and reconstituted body that reflects both psychoanalytic models (of hysteria, mainly) and the pressures of being a body in the midst of chaotic modern life, as these issues are reflected in cinema and poetry. While she primarily addresses four other modern poets (Moore, Stein, Loy and Williams), she devotes a portion of her introductory chapters to Pound and Eliot, and notes how cinematic influences drive the meanings that arise in their work. For instance, she argues that in his poem "In a Station of the Metro": "Pound engenders a cinematic space that amounts to the "filming' of commuters rushing through a station." McCabe, 2005, p. 33.

16. Margaret Atwood, "Happy Endings," Murder in the Dark: Short Fictions and Prose Poems, Toronto, Coach House Press, 1983, p. 40. 
Rhythm is one of the key factors of connecting with other media upon which these filmmakers draw. On one end of the spectrum, as a filmmaker like Henri Chomette demonstrates ${ }^{17}$ the rhythm of a cinematic passage is entirely the point:

[Cinema] has already created a sort of rhythm. [...] Thanks to this rhythm, the cinema can draw from itself a new potentiality, which, leaving behind the logic of events and the reality of objects, engenders a series of visions that are unknown - inconceivable outside the union of the lens and the moving reel of film. ${ }^{18}$

On the other end of the spectrum, the meaning of a cinematic passage is abetted by a rhythmic presentation, abstract or not. Take for instance Bruce Conner's Report, where segments of white alternating with black create an increasing noisome flicker effect that coincides with the activation of the film's theme of mediating death:

The trauma and chaos of the moment of the assassination is "illustrated" by the flickering alternation of black-and-white frames. [...] This section has been discussed as an attempt to simulate the fluctuating consciousness of the dying Kennedy, but its affect $[\ldots]$ acts to communicate the limits of representation (particularly in relation to death). ${ }^{19}$

This thematic motivation coincides with what Adrian Danks has termed Conner's interest in "sculptural assemblage": the means for characterizing this representation is, strictly speaking, a very abstract rhythm (black and white in alternation). From both ends of the spectrum-rhythm for its own sake or for narrative, abstract or other purposes - and at all points in between, we can observe the rewards and the descriptive powers that a model of poetry, music, or dance holds for theorizations of cinema. Simply put, a model based on these particular

17. See for instance Henri Chomette, Cinq minutes de cinéma pur (1925) or his remarks on the matter quoted in René Clair's Cinema Yesterday and Today, New York, Dover Publications, 1972, p. 98. See also Jean Goudal's "Surrealism and Cinema," which emphasizes the way in which cinema's rhythm (both of music and images) promotes access to a surrealistic, hallucinatory state. In The Shadow \& Its Shadow: Surrealist Writings on the Cinema, trans. and ed. Paul Hammond. San Francisco, City Lights Books, p. $87-88$.

18. Henri Chomette, "Second Stage," in Abel, 1988, p. 372.

19. Adrian Danks, "Shooting the President: Bruce Conner's Report," Senses of Cinema, archive.sensesofcinema.com/contents/cteq/og/5o/report.html (last access on January 18, 2011). It is interesting that Danks fixates on the idea of "sculptural assemblage," a principle here used to describe the collage effects that appear in Conner's work, but more usually applied to actual sculpture, returning us to the collapse of media, "sculpted" prose, and thus toward Pound's poetics, which likewise at times evokes sculptural collage. 
vehicles of meaning provides insights which one fixed on causality or plot structure or something else offers only incompletely. In order to grasp the expressive capacities of mise-en-scène, cinematography, sound, and especially montage, we would do well to consider the affinities between poetry and cinema, with special emphasis on the notion of rhythm inherent in each.

Although the implications of the intersections between poetry and cinema are far-reaching and extend beyond modernism, a series of three more focused examples will demonstrate the value of considering rhythm as the connecting point between cinema and poetry, particularly in the modern age. First, Ezra Pound exemplifies the tendency to use a poetic response to cinema through his poem "Hugh Selwyn Mauberley", albeit a negative one. He marshals cinema to express anxiety about his dying medium at a moment of cultural change. However, his juxtaposition unconsciously points the way to a more productive yet less explored association between these media, in part in their underlying shared desire to overcome narrative structures. Drawing on the example of Pound's formulations, this essay will then consider one of the central examples of the cinema's relationship to poetry through rhythm in the 19zos examining the work of Germaine Dulac. Finally, it will move briefly out of the modern era to suggest how the models developed in that era bear fruit well beyond it, as the cinema of Maya Deren suggests.

While Hollis Frampton cites a lost Vorticist film that Pound possibly worked on with Alvin Langdon Coburn, ${ }^{20}$ as Susan McCabe notes, Pound exercised a "relative reticence about arguably the most revolutionary art form of [his] time": the cinema. In 1918, Pound declared: "The cinema is not Art."21 Nevertheless, at this moment of intermedial experimentation intermediality and experimentation, Pound's work shows us a kinship between these media. Several of Pound's poems-including the seminal "Hugh Selwyn Mauberley", a poem that has been

20. Hollis Frampton, On the Camera and Consecutive Matters, Cambridge (Mass.), MIT Press, 2009, p. 27.

21. Cited in Kenneth Knowles Ruthven, A Guide to Ezra Pound's Personae, Berkeley, University of California Press, 1969, p. 130. Ruthven glosses Pound's dismissal of the cinema, writing that Pound believes it is not an art "because [cinema] is a mechanized form of passive impressionism, and not of active instigation." Ruthven notes that Pound revised his thinking somewhat after encountering Jean Cocteau's Poésies, and that "Pound was using juxtaposition as a structural device before he saw Eisenstein's analogous experiments with the cinematic cut." 
described as leading decisively toward the Cantos ${ }^{22}$-employ the type of rhythm and poetic inventiveness he demanded, while simultaneously articulating concerns specific to cinema. As suggested in the first section of "Mauberley" entitled "E.P. Ode pour l'érection de son sépulcre," Pound's work is troubled by reference to the cinema:

The "age demanded" chiefly a mould in plaster,

Made with no loss of time,

A prose kinema, not, not assuredly, alabaster

Or the "sculpture" of rhyme.

The use of the word "kinema" (besides reminding us of the potential kineticism which cinema mobilizes by linking still images in an illusion of motion), alerts us to the exclusionary principle of Pound's poetry (citation of other languages and traditions, the reader be damned if she doesn't know them) and the inclusivity of cinema, which arrives like a throwaway daily paper on the doorstep of the modern moment to usurp such exclusive realms. Even a cursory read of these lines points to Pound's anxieties about the place of poetry among the arts, even while he ironically and probably unwillingly suggests, through the vehicle of poetry, a viable and kindred alternative for its own devices in cinema. Moreover, making "prose" and "kinema" coterminous employs something akin to a montage principle, where two ideas that do not seem to belong together collide into a new, third term meaning, a strategy common in poetic composition which also drives cinematic language.

These lines assert the mode expressed in Pound's notion of poetic rhythm, which dictates not a predictable regularity but an overall arc of phrasing based on more subtle rhythms. "Hugh Selwyn Mauberley"s rhythm depends more on subtle variations than on metronomic time. Though there are repetitions ("not, not assuredly," and the quotation of "age demanded," which repeats lines from earlier in this same poem) and rhymes (time/rhyme and alabaster/plaster), and

22. The connection to song articulated by the Cantos is apparent as even the title suggests, as well as its several allusions to the troubadour tradition; "Mauberley" serves as a clear precursor to that poem. For discussion on the similarities between the works, see, for example, Frank Raymond Leavis, New Bearings in English Poetry: A Study of the Contemporary Situation, London, Chatto and Windus, 1959. Pound had already published the first three Cantos and by 1919 had drafted the fourth. "Hugh Selwyn Mauberley" was fundamental in his conception of the Cantos, as seen, for example, in changes he made to the Cantos he published in 1917 after he wrote "Mauberley." I am grateful to Leah Culligan Flack for pointing out this pertinent chronology. 
though sometimes the line nods to regular meters (the second and fourth lines especially coincide), the overarching logic of the poem's versification follows the principle of relationship (rather than regularity) so important to studies of prosody. The internal and deep slant rhymes of mould/no/prose, for instance, build a subtle sense of rhythm through repetition of sound in the lines, without adhering strictly to a rigid pattern. Poets as different as Paul Valéry ${ }^{23}$ and Robert Pinsky, ${ }^{24}$ have characterized the matter of rhythm in similar ways: marking rhythm-in a poem, a dance, music, cinema-requires relativity. Simply put, one cannot detect rhythm without a sense of either subtle or blatant variance. For Pound, rhythm is not hammered out but "sculpted". Variations of the poem's rhythm depend on and drive the poem's sense.

Pound reluctantly indicates a relationship between cinema and poetry, but the resonances suggested in "Hugh Selwyn Mauberley" (though all but unexplored by Pound himself) are strong. The way in which he writes out the "loss of time" of these lines refers as much to the lack of meter (time/duration) in non-poetic projects as it does to Pound's demands upon his own poetry to achieve that level of dynamism without foregoing the power of the line. However ironically, Pound directs us to the idea of what the prosody of poetry can accomplish as a vehicle for particularly modern thought. Cinema in fact enacts "no loss of time," because it depends upon the temporal dimension (just as does poetry) for its effects. Moreover, between poetry and cinema there is a similarly positive endowment of rhythm in each medium; each likewise manipulates the terms of rhythm inherent to it in order to "sculpt" meaning from raw form.

In these lines and elsewhere, Pound effects the collapse of several art forms, a move typical of the modern context: in this case, sculpture, poetry and cinema. ${ }^{25}$

23. On the heels of suggesting the lack of a systematic definition of rhythm in his work, Valéry notes: "Without knowing it, the Poet moves within an order of possible relationships and transformations, perceiving or pursuing only those passing and special effects which are of use to him in a particular phase of his inner activity." Paul Valéry, "Problems of Poetry," The Art of Poetry, Princeton, Princeton University Press, 1989, p. 93-94.

24. Pinsky, for instance, insists that reading versification requires a system of relativity: "The stressed syllable is determined only in relation to the other syllables within the foot." Pinsky, 1998, p. 14.

25. For elaboration of the intermediality of this period, see Marjorie Perloff, The Futurist Moment, Chicago, University of Chicago Press, 2003. Moreover, John Espey draws the intertextual connection between Pound's "Mauberley" and his source material in Théophile Gautier's poetry, see John Espey, Ezra Pound's Mauberley, Berkeley, University of California Press, 1974. 
Such a collapse ("the 'sculpture' of rhyme," for example) harkens us simultaneously to the rampant, experimental artistic intermediality of the modern moment ${ }^{26}$ as well as to the distrust of the increasingly porous boundaries among media. Indeed, Pound calls into question the relative value of one art form over another, putting derisively aside in scare quotes the notion that "sculpture" and rhyme can meaningfully be brought into juxtaposition. ${ }^{27}$ However, for several of Pound's contemporaries, the cinema is exactly the sort of vehicle that a modernist might seek in order to actuate the rhythms of the age-mechanical rhythms, Taylor girl synchronizations, and the acceleration of modern life among them. ${ }^{28}$

In fact, moreover, the contrast Pound stresses in these lines is actually less between divergent media than divergent literary modes: prose versus poetry. Thoughts shaped into verse are supposed to endure (in earlier times, verse was the way poems endured, because verse made them easier to remember and therefore more likely to be passed from audience to audience), but the relatively soft or expendable materials suggested by "alabaster" and "plaster" respectively suggest otherwise. Indeed, for Pound, verse in and of itself is not sufficient to make poetry. In several contexts, Pound insists that although rhythm in a general way is of utmost importance, the specific versification requires great flexibility. He rails against the constricting forces of traditional verse and supports the notion of vers libre or the sounds of other kinds of musicality than those asserted (especially) by pentameter. ${ }^{29}$ In his construction of melopoeia, for instance, rhythms are more important than meaning: melopoeia occurs when "the words are charged, over and above their plain meaning, with some musical property, which directs the

26. Pound's own musical compositions suggest as much.

27. This derision is also part of his reassessment of his Imagist poems, so that "Hugh Selwyn Mauberley" may be seen as Pound's burial of one style and birth of another. Hollis Frampton ruminates on Pound's transformation of his praxis, noting for example Pound's comment in a 1914 letter that "it took him ten years to learn his art, and another five to unlearn it." Frampton, 2009.

28. See also, for further corroboration of this impulse, Hart Crane's essay "Modern Poetry," which argues that "... unless poetry can absorb the machine, i.e., acclimatize it as naturally and casually as trees, cattle, galleons, castles and all other human associations of the past, then poetry has failed of its full contemporary function." Hart Crane, The Complete Poems and Selected Letters and Prose, ed. Brom Weber, New York, Anchor Books, 1966, p. 261-262.

29. It is important to note that Pound, in his mastery of vers libre, derided those who in his opinion did not: "Vers libre has become as prolix and verbose as any of the flaccid varieties of verse that preceded it $[\ldots]$ at times the writers seem to follow no musical structure whatsoever." Ezra Pound, Make It New, London, Faber and Faber, 1934, p. 336. 
bearing or trend of that meaning." ${ }^{30}$ Poetry whose primary nature involves melopoeia cannot be translated without losing its force, because its primary quality is its sound, aligning it with music. ${ }^{31}$

Pound revisited the idea of rhythm throughout his poetic career. He sought a way to, in Eliot's phrase, "enlarge our sensibilities" by an expansion of the notion of rhythm in English versification. As William McNaughton's work on Pound's meter argues, Pound did not toss out meter altogether when he chucked the influence of regular English meters like the pentameter; instead, he substituted the rhythms of musical phrasing and of other languages' typical meters (including Spanish and Greek, by Pound's own admission). ${ }^{32}$ Rather than strict metrics, Pound sought "an 'absolute rhythm'... that corresponds exactly to the emotion or shade of emotion to be expressed," 33 linking rhythm to the effects it could enact upon the reader rather than to the limits of classical forms. As we shall see, in cinematic discourses on the subject, the impact on the audience is one of the primary reasons to employ rhythm in the cinema.

Rhythm-of the musical phrase rather than the metronome-is mobilized in both narrative and non-narrative forms in the work of French filmmaker and theorist Germaine Dulac, who explores film as "a visual symphony made of rhythmic images." ${ }^{34}$ Dulac depends heavily on the development of themes through the direct use of poetry, music, and even dance in her films ${ }^{35}$. In $\mathrm{La}$ souriante Madame Beudet (1922), for instance, Madame Beudet and her husband are contrasted through their divergent musical interests (Debussy vs. opera). In L'invitation au voyage (1927), the title and subsequent themes of the film are

30. Pound, "How to Read,"1954, p. 25.

31. On the thorniness of translating melopoeiac poetry, see Reginald Gibbons, "Poetic Form and the Translator,"Critical Inquiry, vol. 11, n 4, 1985, p. 654-671.

32. In the Pisan Cantos, Pound reflects back on the representational experimentation of the high modernist era and remembers, "To break the pentameter, that was the first heave" (Canto LXXXI). Quoted in William McNaughton, "Ezra Pound's Meters and Rhythms," PMLA, vol. 78 n 1, 1963, p. 136.

33. Pound, "A Retrospect," 1954, p. 9.

34. Germaine Dulac, «Les Esthetiques, les entraves, la cinégraphie intégrale,» Écrits sur le Cinéma: 1919-1937, ed. Prosper Hillairet, Paris, Paris Expérimental, 1994, p. 102.

35. The use of gesture as another means of expressing rhythm cinematically finds elaboration in the films of Maya Deren (particularly A Study in Choreography for Camera [1945], Ritual in Transfigured Time [1946], and The Very Eye of Night [1958], all of which employ professional dancers) and in several recent films made of sign language poets performing their poetry, including Dutch poet Wim Emmerik's Reflection (2001). 
based on Charles Baudelaire's poem of the same name. In Thèmes et variations (1928), a ballet dancer mimics machines' movements.

Dulac's films engage music and rhythm on the visual level as well. For example, despite its primarily narrative format, La souriante Madame Beudet accumulates visual rhythm, which builds ultimately toward a climax:

[...] simple gestures, simple looks by Madame Beudet toward her husband-but one will feel through the course of the film the intensification of these looks [...] announcing the final drama. This progression $[\ldots]$ works above all through the play of shots and their rhythm. ${ }^{36}$

Dulac's editing and her rhythmical sense-a musical sense-both underscore the narrative movement of La souriante Madame Beudet and create meanings of their own, founded on conveying a feeling generated, here, through the acceleratory power of rhythms. To borrow a musical term, it is the crescendo of the film's montage that builds up to the climax. Dulac orchestrates that rhythm and evokes emotions through it.

In addition to the praxis of her films, Dulac's theoretical writings often cite music and poetry in relation to cinema. Laurent Guido has convincingly categorized Dulac as a key figure embodying the "age of rhythm," the period of the 1910s-1920s when discourses surrounding the arts, and especially the cinema, were indelibly marked by the question of rhythm. ${ }^{37}$ Guido demonstrates the often contradictory nature of the comparison drawn between cinema and music in Dulac's thinking. For instance, rhythm is both concrete, even geometrical in its construction, and numinous, having validity as an expressive technique mainly in the realm of the ineffable, of the fleeting sensation..$^{38}$ Similarly, in Richard Abel's account of the debates around pure cinema in France at the end of the 1920s, he notes that at that particular moment in her career Dulac shifts away from narrative form: "Dulac... imagine[s] a cinema entirely autonomous from narrative [...] [She] now repeatedly defends a non-representational cinema that would bring to the surface from the depths an "imperceptible music." ${ }^{39}$ Her move

36. This assessment of the film derives from Dulac's former secretary, who recollects her comment about the film. L.B. Danou, Le cinéma de ma mémoire: en hommage personnel à Germaine Dulac, telle que je l'ai connue, Paris, Jouve, 2005, p. 22.

37. Laurent Guido, L'âge du rythme: Cinéma, musicalité et culture du corps dans les théories françaises des années 1910-1930, Lausanne, Payot, 2007.

38. Ibid.

39. Richard Abel, "The Great Debates," in Abel, 1988, p. 332. Abel cites evidence for his claims through Germaine Dulac, "Les esthétiques, les entraves, la cinégraphie 
toward non-representational cinema suggests less an abandonment of narrative, however, than a desire to see how far the musical analogy might stretch.

Poetry provides an even more provocative and recurrent model for cinema, and Dulac employs it in relation to the musical example, based in rhythm. For example, she notes: "One has copiously denied in the course of recent inquiries the poetic possibilities of the cinema. This attitude has disconcerted me because the cinema is poetry itself, much more than theatre, much more than spectacle." 40 In addition to the directness of Dulac's formulation of the similar potential each medium traverses, we should note Dulac's use of metaphor as rhetoric: "cinema is poetry." That is, her thinking is influenced as much by poetry and musical analogy as by the terms of cinema. The way in which she argues cinema ought to be metaphorized as poetry highlights cinema's rhythms. She points to the way the cinema mobilizes multiple systems of meaning (point and counterpoint, rhythm and counter-rhythm, melody and harmony) at once: "It is rhythm in its oppositions and concordances. It is harmony." ${ }^{41}$ Dulac uses the poetic analogy in order to direct attention to the potentiality of cinema's techniques as expressive tools. In contrast to Pound's distrust of the cinema, Dulac is euphoric about poetry's possibilities for explaining how the cinema works. But whatever their orientation, both artists sail the same ship: for both, shaping images and ideas through rhythm builds into meanings that cannot be accessed through mere prose or the traditions that precede their art. ${ }^{42}$

One of the clearest inheritors of the modernist connection between poetry and cinema in regards to rhythm is Maya Deren, whose thinking about cinematic temporality derives directly from her engagement with poetry and the thinking of the modern poets. As Renata Jackson has pointed out, both Pound and T.S. Eliot were enormously influential in Deren's thinking about her endeavors in poetry and cinema; Deren wrote her master's thesis at Smith College on French symbolist poets in relation to Pound and Eliot; she also wrote a great deal

intégrale," L'art cinématographique, vol. 2, no 46; "Du sentiment à la ligne," Schémas, $n^{\circ}$ 1, February 1927, p. 26-31; "La Musique du silence," Cinégraphie, nº 5, January 15, 1928, p. 77-78; and "Films visuels et anti-visuels," Le rouge et le noir, July 1928, p. 31-41.

40. From the Dulac archives at the Bibliothèque du film (Paris), DULAC Box 311, Folder 3 .

41. Ibid.

42. See also Pound's essay on Henry James, where he argues for the power of poetic expression over and above prose. Pound, 1954, p. 295-338. 
of poetry herself. ${ }^{43}$ Through the Symbolists and poetry more generally, Moira Sullivan has argued, Deren first articulated her concerns with ritual and myth, and these became "a guiding force in her creative work." ${ }^{44}$ Specifically, Sullivan notes that "the symbolist effort to spiritualize language and Eliot's mystical method" were influential for Deren. Both of these tendencies exemplify the ability of poetry to point in the direction of the ineffable. P. Adams Sitney has also associated Deren's film work with Imagism, linking her impulses all the more intimately with Pound and his associates. ${ }^{45}$ Her final film project she deemed "a filmic haiku” (see Fig. p. 129). But for Deren, one of the most perceptive statements of the "poetic" nature of cinema comes in her participation at Cinema 16's symposium on cinema and poetry (1953), which included fellow filmmakers and/or theorists Willard Maas and Parker Tyler, the poet Dylan Thomas, and dramatist Arthur Miller. Here, Deren articulates her theory of the "vertical" nature of poetry and cinema in opposition to the horizontal thrust of narrative or a dramatic arc, although these latter forms are not completely devoid of the vertical: for example, Deren cites the monologues in Shakespeare as belonging to the vertical tendency. The possibility of wedding these tendencies in Deren's formulation might allow for a better scansion of narrative and poetic films that meaningfully engage both. An awareness of where the rhythms are and how they emerge in relation to other rhythms helps us to mark out the specifics of the keeping of cinematic time.

Deren shows how the poetic model matters in a study of modernist cinema by asserting that such a model is needed because it represents the language and logic that fuels her own creative efforts. In A Study in Choreography for Camera (1945), Deren manipulates the temporal realm available to the camera (through slow motion, temporal elisions, fast motion) to create a reality uniquely possible in the cinema. For instance, when Talley Beatty spins beside the Bodhisattva statue behind him, both faces (his and the Janus-faced statue) appear to be in

43. Renata Jackson, The Modernist Poetics and Experimental Film Practice of Maya Deren, Lewiston, Mellen Press, 2002.

44. Moira Sullivan, "Maya Deren's Ethnographic Representation of Ritual and Myth in Haiti," in Bill Nichols (ed.) Maya Deren and the American Avant-Garde, Berkeley, University of California Press, 2001, p. 208.

45. P. Adams Sitney, "Imagism in Four Avant-Garde Films," in Film Culture Reader, New York, Cooper Square Press, 2000, p. 188. 
more than one place at one time, especially when the spin accelerates and his head becomes blurry. ${ }^{46}$

The relative stasis of the statue-as a stand-in for plastic arts more generally-draws attention to the difference cinema makes (motion, which must express rhythm through its intersecting variations here). The combination of Beatty's spinning movement with the camera's varying speed of movement (note that the shot begins in slight slow-motion and gradually speeds up until it reaches a slightly fast-motion) underlines Deren's film practice : she employs a camera not simply to objectively record Beatty's dance, but to expose the uniquely harmonious cinematic/rhythmic/terpsichorean nature of her endeavor.

Modern poetry sought, as Wallace Stevens insisted (despite or even because of the "rage for order"), a different kind of music, possessed of "keener sounds." Even for Ezra Pound, a modernist so reluctant to admit the benefits of a cinematic way of thinking, the rhythm inherent in cinema, a part of its unique purview, finds important echoes in the exigencies of his own ideas about modern poetry. For Dulac, a figure central to the utopian way of thinking about rhythm in the cinema, and for Deren, an inheritor of this way of thinking beyond the modern age, the intersection between poetry and cinema expressed through the ideas of rhythm in modern poetry is crucial. The connection between poetry and cinema-between these two vehicles for artistic expression in modernity-sheds light on both, underlining the indirect way they create meaning for those for whom narrative and the banality of prose were not enough to express the feeling, thought and experience of the age.

46. In relation to this shot, P. Adams Sitney has significantly noted that the close-up framing of Beatty's face brings the two figures together in a metaphorical relationship: "The implied metaphor identifies the dancer, whose twirling head seems to face all directions at the same time, with the statue and relates to the theme of the ambiguity of space (here, direction)." Ibid., p. 188.

47. From "The Idea of Order at Key West," Wallace Stevens, The Collected Poems, New York, Vintage, 1990. 